Article

\title{
Glacial Stream Ecology: Structural and Functional Assets
}

\author{
Leopold Füreder * and Georg H. Niedrist ${ }^{\mathbb{D}}$
}

River and Conservation Research, Department of Ecology, University of Innsbruck, Technikerstr 25, Innsbruck 6020, Austria; georg.niedrist@uibk.ac.at

* Correspondence: leopold.fuereder@uibk.ac.at; Tel.: +43-512-507-51740

Received: 15 November 2019; Accepted: 23 January 2020; Published: 30 January 2020

\begin{abstract}
High altitude glacier-fed streams are harsh environments inhabiting specialized invertebrate communities. Most research on biotic aspects in glacier-fed streams have focused on the simple relationship between presence/absence of species and prevailing environmental conditions, whereas functional strategies and potentials of glacial stream specialists have been hardly investigated so far. Using new and recent datasets from our investigations in the European Alps, we now demonstrate distinct functional properties of invertebrates that typically dominate glacier-fed streams and show significant relationships with declining glacier cover in alpine stream catchments. In particular, we present and argue about cause-effect relationships between glacier cover in the catchment and temperature, community structure, diversity, feeding strategies, early life development, body mass, and growth of invertebrates. By concentrating on key taxa in glacial and non-glacial alpine streams, the relevance of distinct adaptations in these functional components becomes evident. This clearly demonstrates that further studies of functional characteristics are essential for the understanding of peculiar diversity patterns, successful traits and their plasticity, evolutionary triggered species adaptions, and flexibilities.
\end{abstract}

Keywords: invertebrates; glacier retreat; Chironomidae; Diamesinae; adaptation; harshness

\section{Introduction}

Freshwaters at high altitude and latitude are often strongly influenced by snow and ice cover of the catchment, resulting in temporal (seasonal) and spatial (longitudinal) variabilities in environmental conditions (e.g., [1-4]). Glacial streams and rivers are for this reason considered as harsh ecosystems, because melting glacial ice in summer contributes significantly to the rough environmental key conditions (low water temperature, increased discharge dynamics, instable substrate and riverbed, increased turbidity and sediment load). Dependent on the size, volume, and mass of the glacier in proportion to the catchment area, a specific degree of harshness shaping and affecting of distinct biological characteristics has typically been observed (e.g., [5,6]). Such harsh environmental conditions in glacier-fed streams and rivers have caused specific adaptations in the biological communities over evolutionary timescales. Today's result is a diverse flora and fauna in these ecosystems, consisting of key taxa of benthic algae and periphyton $[7,8]$ and invertebrates, such as the insect family Chironomidae, the chironomid subfamily Diamesinae, and species within the chironomid genera Diamesa and Prodiamesa [6]. Besides the typical structural components of biodiversity, functional characteristics and patterns in glacial streams and rivers have rarely been studied (but see [9-13]).

Glacial streams are not only special ecosystems with certain environmental harsh conditions and typical biological characteristics, with their location at higher altitude and latitude, they are facing considerable effects from climate change. Retreating glaciers as a conspicuous result of climate 
warming will alter environmental conditions, as glacial share in runoff and coherent degrees of harshness typically depend on catchment glaciation.

Differing habitat conditions between streams, and also changing conditions within same waters, produce a mosaic of distinct habitat templates in alpine streams and consequently shape benthic invertebrate communities. In theory, individual traits and the phenotypic plasticity of distinct species limit their range of suitable habitat conditions for their occurrence [13-15], which in summary mediate the composition of occurring invertebrate communities.

While research upon impacts of glacier retreat has focused mostly on the effects for the biodiversity of invertebrates (as reviewed in [16]) and the composition of their communities, far less attention has been given to functional aspects of biota, such as potential consequences for their egg development, their trophic performance, and the acquisition of body-mass. As such functional characteristics might affect population fitness, or also ecosystem functions of alpine streams, such as secondary production, functional aspects of invertebrates-apart from mediating the occurrence of species-seem to be of high importance for the ecological integrity of alpine stream networks.

Here, we present results from an ongoing long-term monitoring of alpine rivers and reanalyzed data from recent studies in order to highlight the relationship between structural and functional properties of glacial stream ecology and the diverse environmental conditions and changes. In remote streams with glacial and non-glacial influence, we assessed invertebrate community metrics, as well as functional aspects such as egg development, body mass formation, trophic preferences, and strategies, and related these with the extend of glacial cover in the respective hydrological catchments. The objective of this study was thus to examine structural and functional assets of biota in glacier-fed streams, and how these might be affected by glacier retreat.

It was the specific aim, by considering multiple structural and functional aspects of alpine stream ecology in regard of glacier retreat, (i) to provide new insights into the limits for most invertebrates and the strategies of glacial stream specialists to survive and successfully reproduce in these harsh environments, and (ii) to come up with a more holistic approximation of consequences due to glacier retreat in alpine stream ecosystems.

\section{Materials and Methods}

\subsection{Study Design}

This study was built upon recent field surveys carried out on alpine streams and rivers within our long-term monitoring program. Besides presenting data on environmental conditions, as well as structural and functional characteristics (assessments in 2014), we re-analyzed some experimental raw data from already published sources (physiological data [17], isotope data [18], and experimental data [19], assessments in 2014, 2015, and 2017, respectively), where we think these new results specifically mirror functional assets in harsh environments, such as glacial rivers. We specifically aimed at defining cause-effect relationships (glacier cover vs. functions) by overlaying the invertebrate community data and environmental settings with the functional characteristics. These results are analyzed along a gradient of glacier-cover in the catchments.

\subsection{Study Area}

Glacial and non-glacial streams were studied in six catchments in the Hohe Tauern National Park in the Central Austrian Alps (Figure 1), where pristine catchments with limited direct anthropogenic influences (such as pollution or hydromorphological alterations) allow conclusions about environmental situations and changes. All selected stream sections are part of a long-term river monitoring project and are located at elevations ranging from 1354 to $2216 \mathrm{~m}$ a.s.l. (above sea level). 


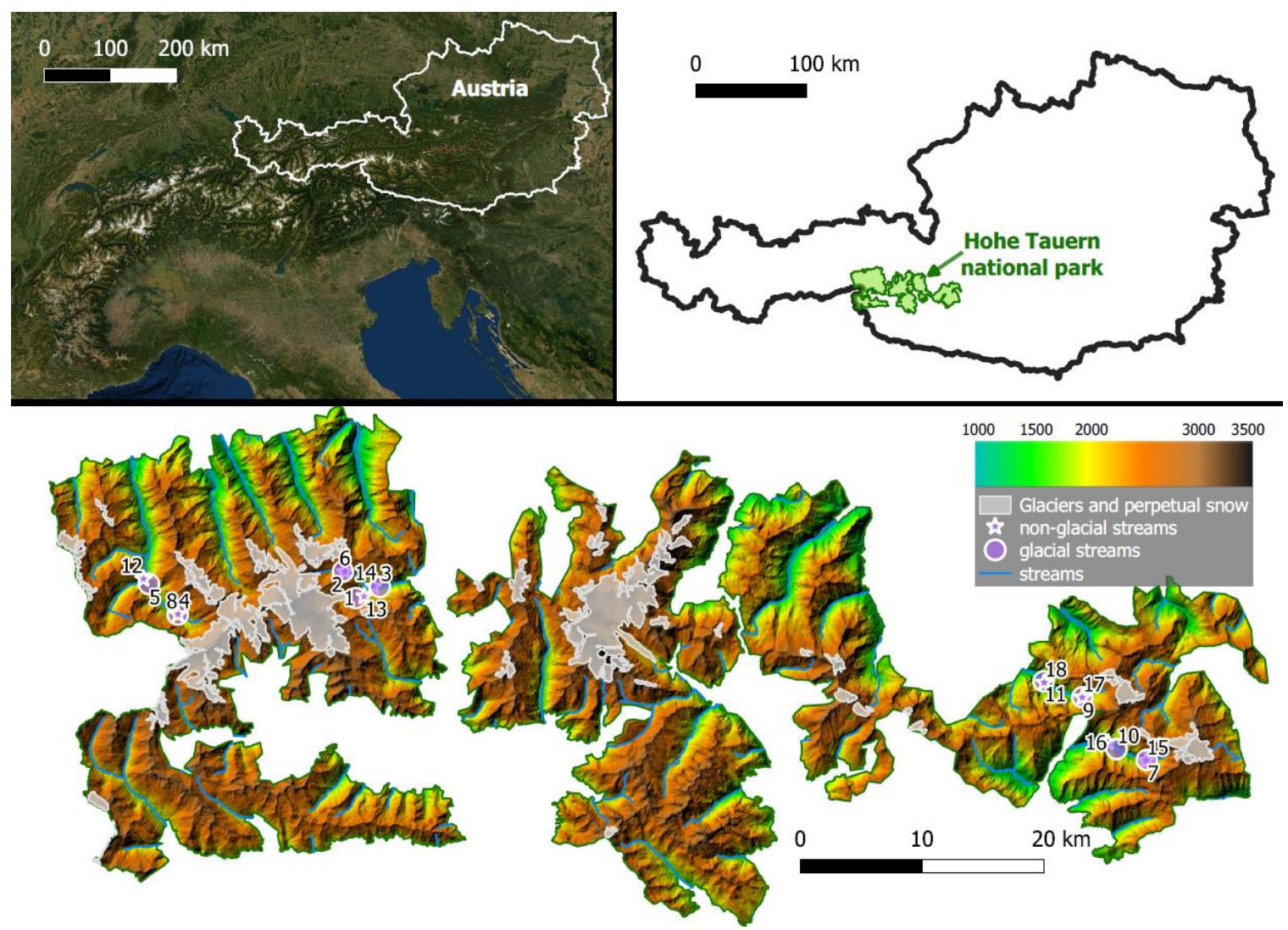

Figure 1. Map of the European Alps, Austria with the Hohe Tauern National Park, Austria, and the sampled stream sections in glaciated and non-glaciated catchments. Colored gradient indicates the distinct elevations within valleys of this mountain range, and circles (glacial streams) and stars (non-glacial streams) locate the sampled reaches. Additional information on study site features are presented in Table 1.

\subsection{Physical and Chemical Habitat Variables}

The degree of glaciation of each catchment was measured using QGIS [20] and CORINE land-cover data, and was expressed as the ratio of glaciated to total catchment area (\%). Stream water temperature was monitored continuously (every $30 \mathrm{~min}$ ) using digital data loggers (Tidbit; Onset, Bourne, Massachusetts) and averaged for a 1 month period before the sampling dates. Suspended solids were quantified via filtering 1-2 L water through pre-combusted Whatman GF/C filters on site and followed by a loss-on-ignition estimation (combustion at $450^{\circ} \mathrm{C}$ for $4 \mathrm{~h}$ ) in the laboratory. Together with the estimated discharge via depth/velocity-transect measurements using a vane wheel probe (ZS25; Höntzsch, Waiblingen, Germany), we modeled the inorganic sediment load (sediment load in $\mathrm{mg} / \mathrm{s})$ as the combination of suspended sediment concentration $(\mathrm{mg} / \mathrm{L})$ and discharge $(\mathrm{L} / \mathrm{s})$.

\subsection{Invertebrate Community Structures}

At each site, in July, we took six samples of aquatic invertebrates with a Surber sampler $\left(0.09 \mathrm{~m}^{2}\right.$, $100 \mu \mathrm{m}$ mesh size) by sampling mesolithal (cobbles), macrolithal (coarse cobbles), and megalithal (boulders) substrates, which represent the main microhabitats in these streams, leading to a total of 108 samples of invertebrate communities. We preserved all samples immediately in $75 \%$ ethanol, identified all groups to the resolution possible, and expressed the community composition using conventional summary metrics for glacier-fed streams, such as invertebrate abundance, taxa richness, or the relative abundance of the dipteran family Chironomidae or its subfamily Diamesinae. 


\subsection{Egg Development in Glacial Streams}

To assess the potential influence of degree glacier cover in the catchment on the egg development of alpine stream invertebrate species, we used experimental data from Schütz and Füreder [19] and compared the identified day-degree demands at distinct breeding temperatures between typical glacial specialists (Diamesinae) and other chironomid species. We then used this published data set (day-degree demand per breeding temperature level, Schütz and Füreder [15]) and combined it with the environmental characters (water temperature and catchment glacier cover) and invertebrate communities of sampled glacial and non-glacial streams in the Hohe Tauern national park. This allowed us to (a) verify the validity of the experimental breeding experiments for alpine streams, and (b) to transfer experimental relationships between water temperature and breeding success to the temperature conditions in the here sampled streams.

\subsection{Bulk Stable Isotopes and Individual Body Mass of Chironomid Populations}

To quantify the potential relationship between glacier influence and trophic performance, as well as the body size of the invertebrates, we used available isotopic niche data of chironomids from Niedrist et al. [18], calculated the isotopic space of each population per stream, and related that to degree of glaciation in the respective catchments. The original data are stable isotope ratios of carbon $\left(\delta^{13} \mathrm{C}\right)$ and nitrogen $\left(\delta^{15} \mathrm{~N}\right)$ of individual chironomid larvae belonging to the taxa (A) Diamesa steinboecki, (B) Diamesa latitarsis-gr.I, (C) Diamesa cinerella-gr., and (D) Orthocladius luteipes, which were sampled in July 2015 using a Surber sampler (mesh size $250 \mu \mathrm{m}$ ). These samples were taken from six different streams with differing catchment glacier cover. In this new analysis of that dataset, we quantified the relationship between each populations' isotopic niche between classes of catchments with differing glacier cover $(0 \%,<15 \%, 15 \%-39 \%, 40 \%-80 \%)$.

To assess the relationship between body mass and glaciation in the catchment, original body mass data of all chironomid taxa belonging to the subfamilies Diamesinae and Orthocladiinae (obtained by Niedrist et al. [17] in the same 18 stream reaches in July 2014) was related with the relative glacier-cover in the respective catchments.

\subsection{Data Analysis}

Relationships between structural community measures (abundance, taxa number, relative abundance of Diamesinae) and glacier cover were tested using simple linear models, considering model diagnosis.

Taxon-specific isotopic niche breadth (isotopic area in $\%{ }^{2}$, quantified via Bayesian Standard Ellipses using SIBER [21]) and its variability of each consumer group per study stream were related with glacial contribution to the glacial stream. For this, the estimated areas per population and sites (in total $>10^{7}$ simulated isotopic niche areas) were related to degree of glacial cover in the respective catchments, indicating median and quantile distribution.

We grouped the individual body mass of each chironomid larvae ( $\mu \mathrm{g}$ individual $^{-1}$ ) per group of sites (catchments grouped by ratio of glaciated area: $0 \%,<15 \%, 15 \%-39 \%, 40 \%-80 \%$ ) and compared the mean body mass of the two subfamilies Orthocladiinae and Diamesinae.

\section{Results}

\subsection{Invertebrate Taxa Number and Dominance of Diamesinae}

In total we identified 204 different taxa in the 18 study streams with their distinct environmental characteristics (Table 1), with most taxa colonizing streams with intermediate and no glacial influence (Table S1). Invertebrate taxa richness increased significantly as catchment glacier cover decreased, with on average +1.5 taxa every $10 \%$ decrease $(p<0.05$, Figure $2 \mathrm{~A})$. In streams with high glacial contribution, invertebrate communities were dominated by Chironomidae, for which relative abundance ranged between $71 \%$ and $98 \%$ (interquartile range). Within the Chironomidae, the relative abundance of larvae 
belonging to the subfamily Diamesinae decreased considerably and significantly with decreasing glacier cover in the streams' catchments $(p<0.05$, Figure $2 \mathrm{~B})$. This relationship indicated a reduction of their relative abundance by $8 \%$ when glacier cover in the catchment decreased by $10 \%$. While the glacial stream specialists Diamesinae dominated the invertebrate community in glacial streams, the relative abundance of the other chironomid subfamily Orthocladiinae gained with decreasing glacier cover in the catchment $(p<0.05)$.

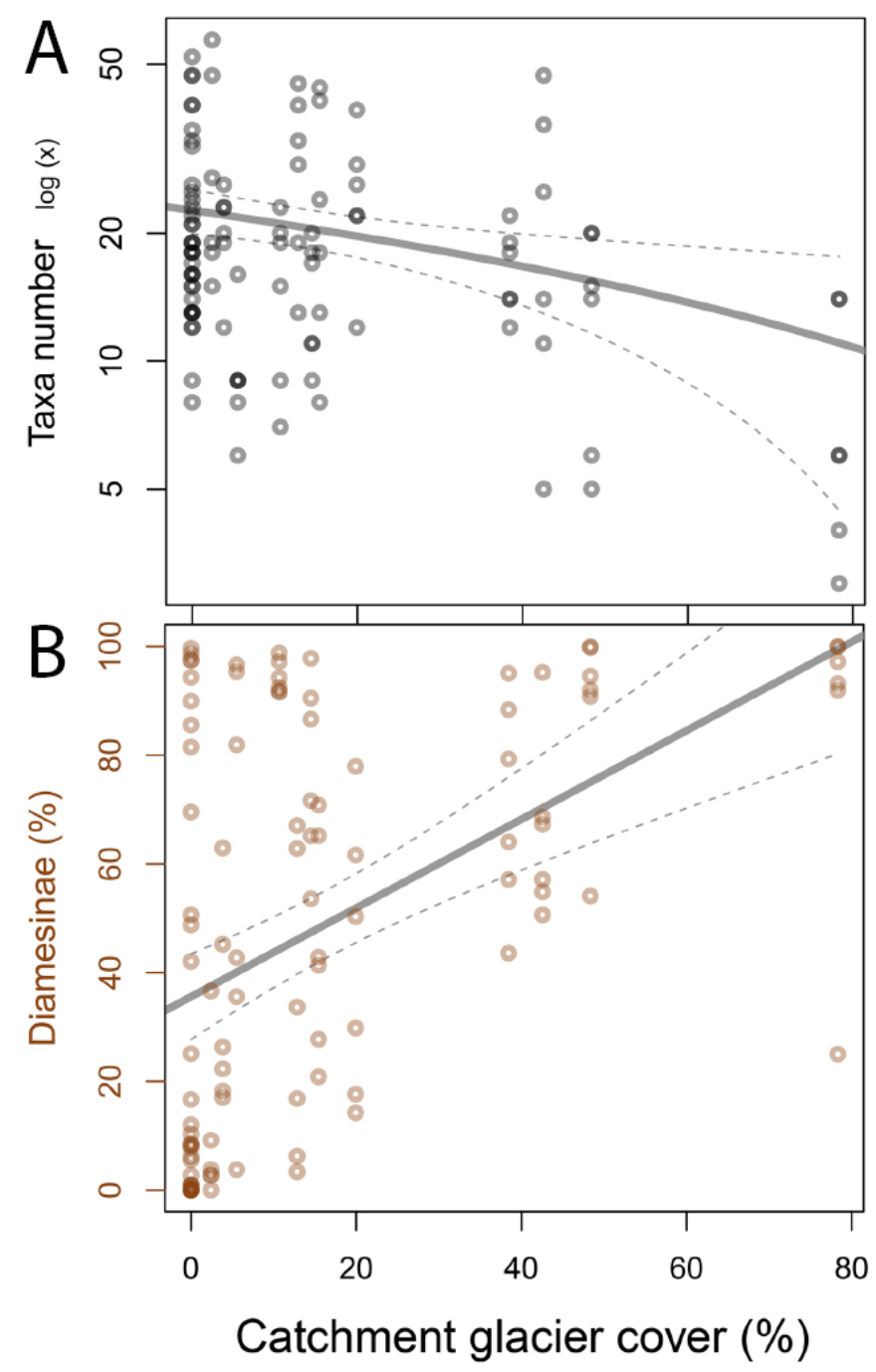

Figure 2. Relationship between catchment glacier cover and the invertebrate community measures (A) taxa number and (B) relative abundance of Diamesinae. Bold lines indicate the linear model fit, dashed lines represent statistical $95 \%$ confidence intervals.

\subsection{Development of Eggs and Larvae in Relation to Catchment Glacier Cover}

In development experiments with chironomid eggs, the degree-day demand until successful hatching was lowest in coldest treatments $\left(2{ }^{\circ} \mathrm{C}\right)$ for all species, but was not related to the habitat conditions (no significant difference between eggs from glacial or non-glacial streams). The averaged original dataset revealed that at the coldest treatment, Diamesinae had a lower day-degree demand (36.2 \pm 7.2) than Orthocladiinae with $52.8 \pm 11.8$ (Figure 3A,B). As highlighted in the original study [19], the averaged degree-day demand across chironomid species was also significantly higher with a higher breeding temperature. The lowest demand was found for Diamesinae in the coldest breeding temperature $\left(2{ }^{\circ} \mathrm{C}\right)$ with on average $36.2 \pm 7$ degree-days, whereas the highest demand of the same subfamily was at $12{ }^{\circ} \mathrm{C}$ with $95.7 \pm 18.8$ degrees-day (Figure $3 \mathrm{~B}$ ). Linking the experimental dataset 
and the invertebrate community data in sampled reaches, we found that the taxa selected for the experiments in [19] were dominant, especially in streams with high glacier cover in the catchment (Figure 3D). While the selected Diamesa taxa contributed considerably to the occurring invertebrate communities in cold and highly glaciated streams (Figure 3D), the contribution of Orthocladiinae taxa selected for the experiment was only marginal in natural non-glacial study streams (Figure 3C). The temperatures selected for breeding experiments in [19] represent significantly $(p<0.001)$ a negative relationship between catchment glacier cover (in \%) and water temperature of the study streams and reflect the natural gradient of summer water temperatures in the same reaches (compare experimental and natural water temperature range, e.g., Figure 3B vs. Figure 3D).
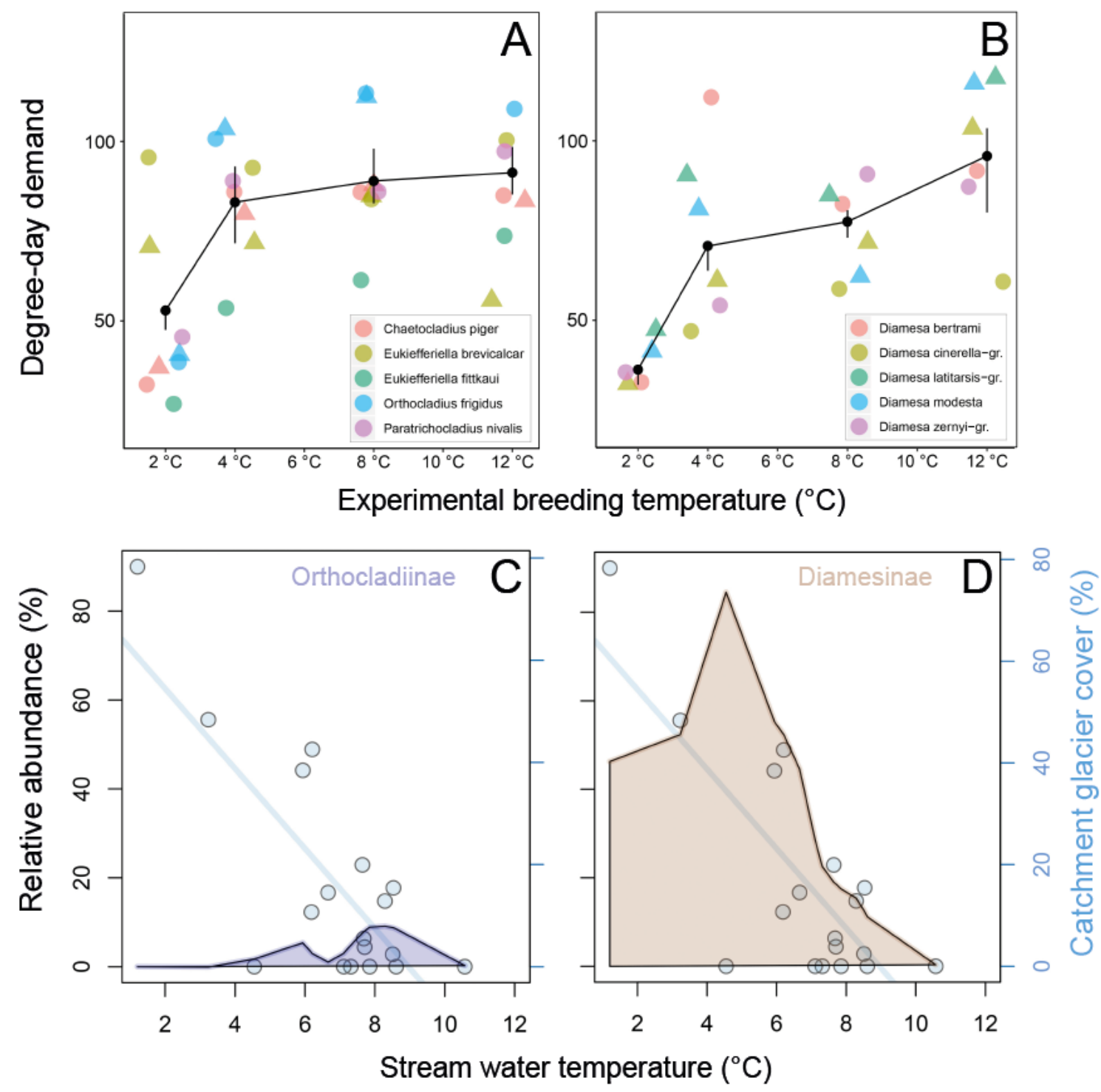

Figure 3. Experimentally derived degree-day demand for successful egg development of Orthocladiinae (A) and Diamesinae (B) species (summarized data (means) from [19]) and their relative contribution to invertebrate communities in studied streams in the present study with Orthocladiinae (C) and Diamesinae (D). The significant relationship $(p<0.001)$ between catchment glacier cover and water temperature is presented in (C) and (D). Dots represents the studied stream sites, representing the catchment glacier cover ( $y$-axis) and the mean temperature one month prior sampling ( $x$-axis). The solid line delineates the modelled linear relationship. Color areas (in (C) and (D)) indicate relative abundances in study streams of the same taxa selected for experiments (those listed in (A) and (B)). 
Body mass of Diamesinae were significantly higher in stream habitats where glaciers covered more than $15 \%$ of the catchment areas, whereas this was not observed for Orthocladiinae (Figure 4). In total, 18,167 individuals were measured, most of which had a body mass between 14.4 and $29.8 \mu \mathrm{g}$ (Orthocladiinae) and 42.9 and $77.5 \mu \mathrm{g}$ (Diamesinae) in catchments with $<15 \%$ glacier cover. While for Orthocladiinae we observed no difference in streams with differing glaciation in the catchment, we found that most Diamesinae had a higher body mass in streams draining highly glaciated catchments (15\%-39\%, Figure 4B) ranging between 75.8 and $128 \mu \mathrm{g}$. The larvae with the highest individual weight of $270 \mu \mathrm{g}$ was a Diamesinae from streams with high glacial input (15\%-39\% glaciation).

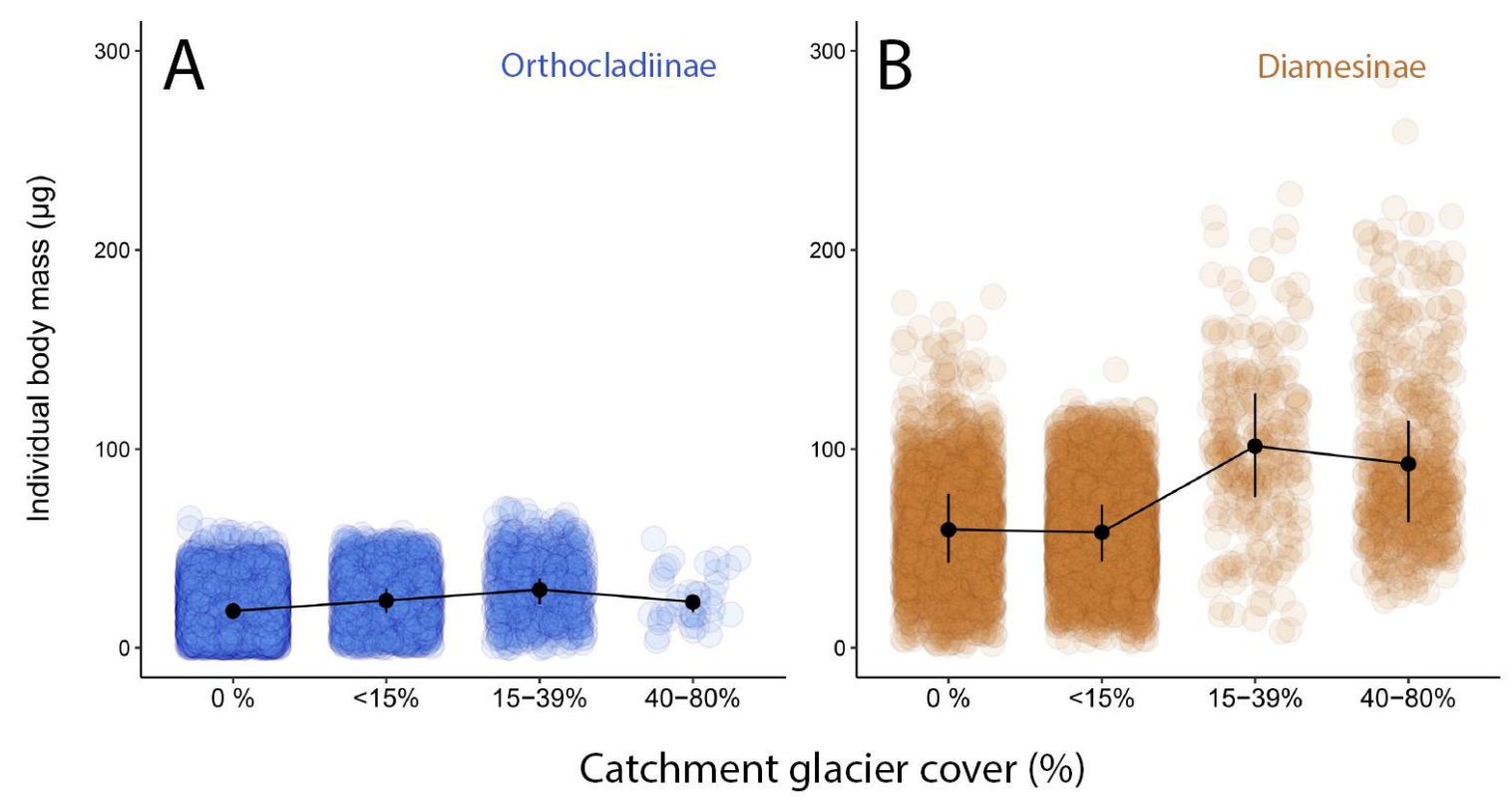

Figure 4. Individual body mass of chironomid subfamilies Orthocladiinae (A) and Diamesinae (B) from groups of streams draining catchments with varying degree of glacier-covered catchment areas $(0 \%-80 \%)$. Single points represent weights of individual chironomid larvae whose weights were determined via length measurements and using available length-mass relationships [22,23]. Black dots represent the mean of each group, vertical lines limit the $25 \%$ and $75 \%$ quartiles of the respective data points.

\subsection{Trophic Strategies in Glacier-Fed Streams Related to Catchment Glacier Cover}

When relating the trophic niche dataset to the glacier cover in the respective catchment (\%), we found that, among the investigated glacial stream specialist taxa, especially Diamesa steinboecki and D. latitarsis-gr.I had significantly larger isotopic niche areas ( $>10$ times higher, Figure 5A) in glacial streams with higher glacier cover, whereas the niche of other taxa (also Diamesa taxa) remained constant, regardless of the distinct ratio of glaciated catchment area. Streams with high glacial cover in the catchment also had lower water temperatures and higher sediment transport, but these relationships were not linear and not the same (Figure 5B). 


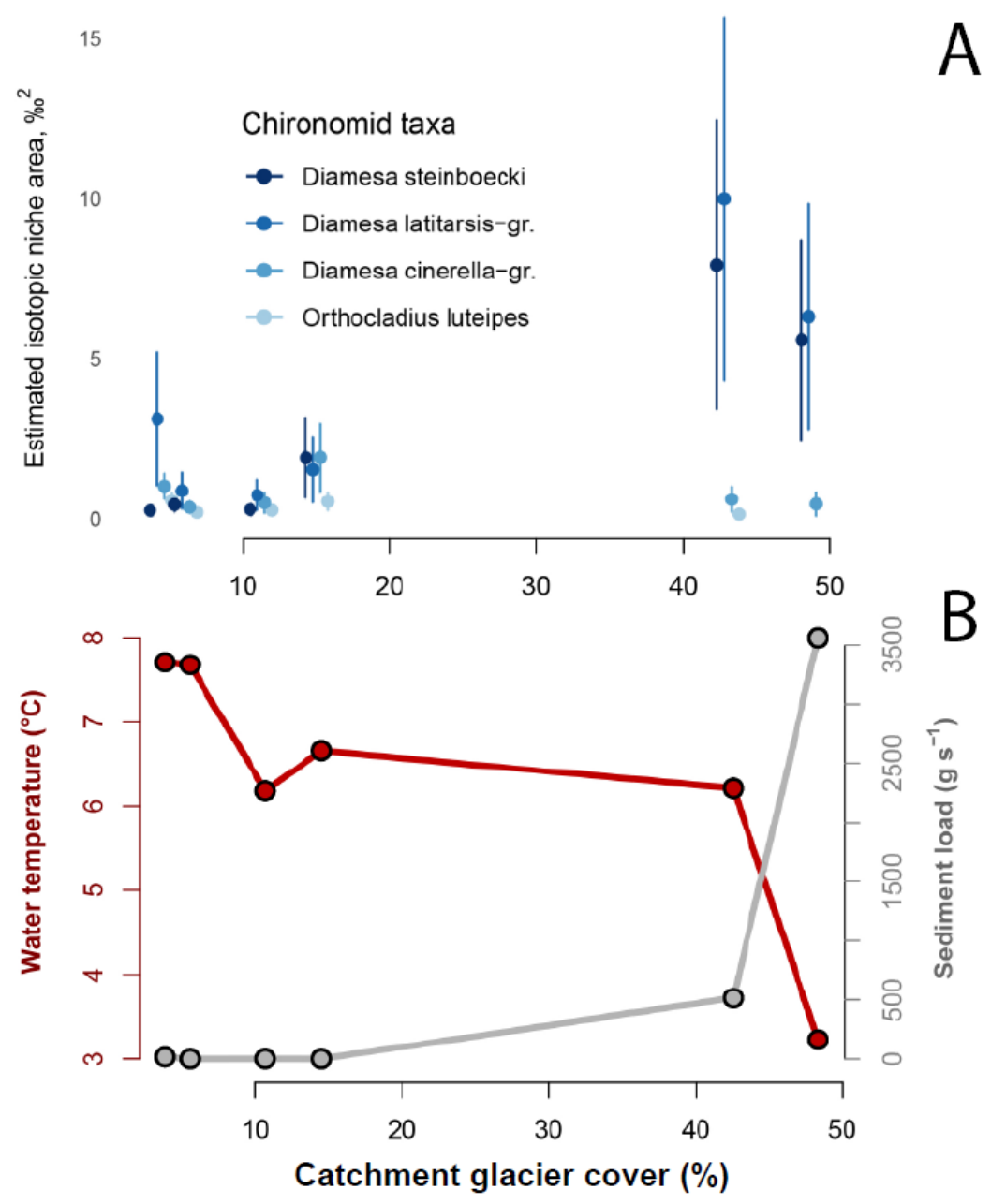

Figure 5. Estimated isotopic niche area (standard ellipse area) of chironomid populations of four chironomid taxa (see legend) from six glacial streams (from [18]) re-analyzed and related with the extend of glacier cover in the respective catchment (\%) (A), which habitats differ in water temperature $\left({ }^{\circ} \mathrm{C}\right.$, in red) and sediment load $\left(\mathrm{g} \mathrm{s}^{-1}\right.$, in grey, B). Here, presented mean and most probable isotopic niche areas (in the $\delta^{15} \mathrm{~N} \times \delta^{13} \mathrm{C}$ isotopic space) were limited using Stable Isotope Bayesian Ellipses in R (SIBER, Jackson et al. 2011) and examined using estimation statistics (using 480,000 (400,000 for $O$. luteipes) bootstrapped samples).

\section{Discussion}

\subsection{Invertebrate Communities in Glacier-Fed Streams Were Dominated by Diamesinae}

The dominance of species of the chironomid subfamily Diamesinae in glacier-fed streams is a well-known phenomenon (e.g., [5,24]), which is also confirmed by our results. With decreasing glaciation in the catchment, their absolute abundance remains constant, but their relative contribution to the total invertebrate community decreases sharply. In the most glaciated stream sections only a few Diamesa species (D. steinboecki, D. latitarsis-gr.I, D. cinerella, and D. zernyi) occur regularly. A second subfamily, the Orthocladiinae, which also dominates in cold streams, shows generally a reverse pattern [25]. With decreasing degree of glaciated catchment area their relative abundance is increasing [26]. Despite the fact that this regular and obvious correlation can serve as an excellent indicator for defining significant effects on the community structure and diversity caused by declining glaciers, we can have a closer look if there are specific functional traits present in these taxa which, in the case of the Diamesinae, enables them to overcome and live in harsh environmental conditions, whereas others (Orthocladiinae) lack these traits. 


\subsection{Functional Assets in Glacial Streams}

The harshness of glacial streams (cold water temperatures, short snow-free periods, or dynamic physical habitat conditions [27]) was long assumed to limit the growth of the invertebrate species that survive there $[28,29]$. In contrast to such assumptions, however, it has been shown that glacial stream specialists typically grow faster in harsh glacial streams or reach higher body mass than the same species in non-glacial streams $[17,30]$. The driving circumstances behind this certainly include the low level of competition in glacial streams [5,18], the sufficient availability of autochthonous and nutritious food resources [17], but also the combination of functional plasticity and special strategies, which are presented and reviewed as follows (and is summarized in Table 2). Although previous studies have highlighted individual functional aspects of glacial stream specialists, this work combined several adaptations and strategies of these taxa and illustrated dependencies on degree of catchment glaciation.

\subsubsection{Fast Development of Eggs and Larvae}

The larval community of glacial streams, dominated by chironomids [24], faces cold and dynamic living conditions not only during their larval stage, but also during their egg development [31], which is the first critical step for the emergence and occurrence of invertebrate species and key for population replenishment. Particularly in glacial streams, in addition to avoiding and tolerating freezing temperatures [32], the successful and timely completion of this stage is necessary for the species to find suitable living conditions as larvae. As for all ectotherms, this first life stage of glacial stream invertebrates is generally temperature-dependent [31,33,34]. Although so far cold-stenothermal species have been assumed to develop most efficiently at low temperatures [35,36], recent laboratory experiments on glacial stream specialist species has revealed their high plasticity against a wide range of temperatures [19], which is not restricted to cold-stenotherm taxa, as confirmed by our results. Thus, species classified as cold-stenotherm in cold waters can comply with a lower number of degree-days until hatching of the larvae, when compared to warmer situations. Conversely, this may mean that glacial stream invertebrates possess a certain plasticity of key fitness-associated traits, such as their reproductive performance, and, in times of warming alpine streams (Niedrist and Füreder, in prep.), that the egg development of specialists itself does not appear to be sensitive to climate change.

Apart from the egg development, it has recently been shown that glacial stream specialist species, in contrast to alpine stream generalists, grow faster in harsh environments (as evidenced by [30]) or produce more biomass than the same taxa in temperate streams [17]. Above a certain threshold of glacial influence, the dominant Diamesinae species are able to enlarge their body mass above the known level, which might be beneficial for their reproductive success.

\subsubsection{Special Trophic Strategies}

The harshness-depending variability of body mass of glacial stream specialists can partly be explained by their plastic feeding strategy, which has previously been observed in the variability of isotopic C signatures [10-12]. In dynamic environments such as glacier-fed streams, where food sources might be patchily distributed due to dynamic riverbeds, glacial river specialists seem to be forced into opportunistic omnivorous or even cannibalistic [37] feeding behavior.

Indeed, an assessment based on stable isotope analysis of chironomid populations in different glacier-fed stream habitats revealed that selected chironomid taxa (Diamesa steinboecki and D. latitarsis-gr.A) exhibit considerably different isotopic niche areas (Figure 5A), indicating a variable diet of the populations when conditions are most dynamic and harsh [18]. While the trophic performance of other taxa (Diamesa cinerella-gr. and Orthocladius luteipes) was not related to environmental conditions in the streams, the isotopic niches of these two typical first colonizers in high glacial streams were many times higher in sites with harsh living conditions compared with that of populations of same species living in more benign habitats (Figure 5A). From these results, we can conclude that the possibility of 
such a plastic feeding behavior within populations is an additional adaptation of these taxa for the survival and dominance in glacier-fed stream.

The harsh conditions in some of the observed glacier-fed streams are based not only on single environmental conditions, but also on the combination of low mean water temperatures, high sediment loads, and generally high levels of glaciation in the catchment (Figure 5B). During climate change and glacier retreat, same habitat properties are expected to change in combination $[4,38,39]$, which in turn means that the trophic and the consequential ecological niche of glacial stream specialists will change. Catchment glacier cover, however, is generally indicating the various gradients of single environmental factors.

In alpine glacier-fed streams, where the short snow-free period is dominated by dynamic river runoff and unstable riverbeds, and where allochthonous organic inputs are typically low, the uptake of enough nutritious food is essential to successfully colonize and reproduce in these environments. Despite the importance of this component, it has long been unclear whether invertebrates in harsh glacial streams can choose between all food sources, or if they have to feed on anything they can find $[10,11]$. In performing gut content analyses of D. steinboecki and D. latitarsis in an Austrian glacier-fed stream and in comparing the relative content of particles with its availability in the habitats of the larvae, these larvae were found to actively select high-quality food sources, namely, benthic diatoms and chrysophytes, but to avoid the low-quality food sources such as cyanobacteria [40]. Thus, such selective feeding can additionally contribute to the success of the glacial stream specialists in harsh glacial streams, as the primary producers diatoms and chrysophytes (e.g., the brown algae Hydrurus foetidus [41,42]) are known to possess distinct physiological properties (different nutritional quality according to fatty acid content and composition [43]). Knowing that such a high nutritional diet can enhance the reproductive success for animals ranging from invertebrates to humans [44], this selective feeding traits of few glacial stream chironomids can be seen as advantageous over other invertebrates in glacial streams.

\subsection{Synthesis and Perspectives}

Overall, this study revealed that invertebrate communities in glacier-fed streams possess distinct structural and functional properties, in contrast to other alpine stream types. The demonstrated functional plasticity of glacial stream specialists emphasizes a strong adaptation of key taxa to successfully live and survive in these cold and dynamic habitats and it significantly adds to the understanding why only specific taxa can survive and form stable populations in these harsh environments and others cannot.

Glacial streams and rivers play a crucial role in feeding lowland running waters in and around mountain areas, such as the European Alps. About $10 \%$ of the earth's land surface is covered by glaciers, which contribute significantly to freshwater availability and distribution. Over the last 170 years, these glaciers have been shrinking steadily, but in recent decades rapidly [45]. This glacier loss has already led to changes in the hydro-morphology and the ecology of river networks, and these are assumed to intensify in the future [46]. Major changes are to be expected not only in run-off and bed-load dynamics, but also in riverine biodiversity and biological community patterns, before we sufficiently understand evolved abilities and adaptations of plant and animal species.

In this respect, studies and experiments for elucidating life-cycle strategies and larval development in the highly adapted invertebrate species are needed. Schütz and Füreder [30] showed that with regular sampling efforts, they were able to conclude on a remarkable larval growth and development in chironomid larvae in the upper-most sections of a glacial river. The here documented similar trend of higher body-mass of chironomid larvae in highly glaciated catchments is another example that extreme environmental conditions may exclude several alpine stream taxa but favor the occurrence of glacial stream key taxa. With these studies $[17,18,30]$ (and results presented here) we may conclude that when the essential needs, i.e., nutrient availability and quality, of robust species are guaranteed, they are able 
to successfully live, grow, and reproduce even at harshest conditions. In amplifying storage of mainly autochthonous organic matter in the ecosystem they enrich the stream food chain at the initial links.

Little is known on the early development of alpine and arctic stream invertebrates. Schütz and Füreder [19] investigated for the first time the potential effect of water temperature on the egg development of 10 cold-adapted chironomid species from glacier- and spring-fed alpine and sub-alpine streams, employing rearing experiments at four different temperature levels. In their comparisons, they found that fast egg development contributed to the success of alpine chironomid species in harsh environments. Our application of functional characteristics again indicates that a fast egg development, together with a fast larval growth, seems to successfully contribute towards the evolutionary fitness of harshness-adapted chironomid species under extreme living conditions that exclude many other benthic species.

These aspects clearly demonstrate that further studies of functional characteristics are essential for the understanding of peculiar diversity patterns, successful traits and their plasticity, evolutionary triggered species adaptions, and flexibilities. Besides distinct structural characteristics and community patterns, knowledge about functional abilities and performance of glacial stream taxa under harsh environmental conditions is needed, especially when recent estimations and reports forecast their rapid changes by the effects of climate and environmental change.

Table 1. Site numbering, location, and environmental character of study sites with average invertebrate taxa number across six surber samples per stream (July 2014): WGS $84=$ World Geodetic System 1984, $\operatorname{maxT}=$ maximum daily mean water temperature (during one month prior to sampling).

\begin{tabular}{|c|c|c|c|c|c|c|c|c|c|c|}
\hline \multirow{2}{*}{$\begin{array}{c}\text { \# Site } \\
1\end{array}$} & \multirow{2}{*}{$\begin{array}{c}\text { Coordinates } \\
\text { WGS } 84\end{array}$} & \multirow{2}{*}{$\begin{array}{c}\begin{array}{c}\text { Catchment } \\
\text { Glacier } \\
\text { Cover }(\%)\end{array} \\
78.3\end{array}$} & \multicolumn{3}{|c|}{$\max T$} & \multicolumn{2}{|c|}{$\begin{array}{l}\text { Transported } \\
\text { Solids (mg/s) }\end{array}$} & \multicolumn{3}{|c|}{$\begin{array}{c}\text { Taxa } \\
\text { Richness }\end{array}$} \\
\hline & & & 1.42 & \pm & 0.1 & 215.2 & \pm 17.4 & 8 & \pm & 5 \\
\hline 2 & $47^{\circ} 8^{\prime} 0.2^{\prime \prime} \mathrm{N}, 12^{\circ} 24^{\prime} 11.8^{\prime \prime} \mathrm{E}$ & 48.4 & 4.97 & \pm & 1.11 & 3559.0 & \pm 142.6 & 13 & \pm & 7 \\
\hline 3 & $47^{\circ} 7^{\prime} 22.4^{\prime \prime} \mathrm{N}, 12^{\circ} 26^{\prime} 37.7^{\prime \prime} \mathrm{E}$ & 42.6 & 7.75 & \pm & 0.84 & 515.2 & \pm 46.6 & 23 & \pm & 16 \\
\hline 4 & $47^{\circ} 5^{\prime} 50.8^{\prime \prime} \mathrm{N}, 12^{\circ} 13^{\prime} 34.2^{\prime \prime} \mathrm{E}$ & 38.4 & 7.68 & \pm & 1.62 & 11.9 & \pm 0.9 & 17 & \pm & 4 \\
\hline 5 & $47^{\circ} 7^{\prime} 9.4^{\prime \prime} \mathrm{N}, 12^{\circ} 11^{\prime} 37.2^{\prime \prime} \mathrm{E}$ & 19.9 & 9.68 & \pm & 1.62 & 16.8 & \pm 0.9 & 25 & \pm & 9 \\
\hline 6 & $47^{\circ} 7^{\prime} 59.8^{\prime \prime} \mathrm{N}, 12^{\circ} 24^{\prime} 19.2^{\prime \prime} \mathrm{E}$ & 15.4 & 12.99 & \pm & 3.23 & 0.1 & $\pm \quad 0.2$ & 25 & \pm & 15 \\
\hline 7 & $47^{\circ} 0^{\prime} 38.7^{\prime \prime} \mathrm{N}, 13^{\circ} 16^{\prime} 40.8^{\prime \prime} \mathrm{E}$ & 14.5 & 9.17 & \pm & 1.89 & 2.1 & \pm 0.3 & 14 & \pm & 5 \\
\hline 8 & $47^{\circ} 5^{\prime} 51.3^{\prime \prime} \mathrm{N}, 12^{\circ} 13^{\prime} 35.2^{\prime \prime} \mathrm{E}$ & 12.8 & 11.24 & \pm & 2.30 & 1.2 & $\pm \quad 0.3$ & 30 & \pm & 12 \\
\hline 9 & $47^{\circ} 3^{\prime} 21.4^{\prime \prime} \mathrm{N}, 13^{\circ} 12^{\prime} 25.7^{\prime \prime} \mathrm{E}$ & 10.7 & 7.54 & \pm & 1.46 & 2.8 & \pm 0.3 & 16 & \pm & 6 \\
\hline 10 & $47^{\circ} 1^{\prime} 5.9^{\prime \prime} \mathrm{N}, 13^{\circ} 14^{\prime} 43.2^{\prime \prime} \mathrm{E}$ & 5.5 & 9.23 & \pm & 1.20 & 1.9 & \pm 0.3 & 10 & \pm & 3 \\
\hline 11 & $47^{\circ} 4^{\prime} 0.9^{\prime \prime} \mathrm{N}, 13^{\circ} 9^{\prime} 53.6^{\prime \prime} \mathrm{E}$ & 3.8 & 8.66 & \pm & 0.92 & 16.8 & $\pm \quad 1.4$ & 21 & \pm & 5 \\
\hline 12 & $47^{\circ} 7^{\prime} 22.1^{\prime \prime} \mathrm{N}, 12^{\circ} 11^{\prime} 15.0^{\prime \prime} \mathrm{E}$ & 2.4 & 10.58 & \pm & 1.48 & 1.9 & \pm 0.3 & 31 & \pm & 17 \\
\hline 13 & $47^{\circ} 6^{\prime} 56.1^{\prime \prime} \mathrm{N}, 12^{\circ} 25^{\prime} 38.4^{\prime \prime} \mathrm{E}$ & 0.0 & 9.59 & \pm & 1.16 & 0.0 & $\pm \quad 0.2$ & 35 & \pm & 14 \\
\hline 14 & $47^{\circ} 7^{\prime} 23.1^{\prime \prime} \mathrm{N}, 12^{\circ} 26^{\prime} 12.6^{\prime \prime} \mathrm{E}$ & 0.0 & 9.38 & \pm & 1.50 & 1.1 & \pm 0.3 & 32 & \pm & 10 \\
\hline 15 & $47^{\circ} 0^{\prime} 36.8^{\prime \prime} \mathrm{N}, 13^{\circ} 16^{\prime} 38.4^{\prime \prime} \mathrm{E}$ & 0.0 & 9.07 & \pm & 1.09 & 0.1 & $\pm \quad 0.2$ & 15 & \pm & 4 \\
\hline 16 & $47^{\circ} 1^{\prime} 22.5^{\prime \prime} \mathrm{N}, 13^{\circ} 14^{\prime} 9.3^{\prime \prime} \mathrm{E}$ & 0.0 & 13.08 & \pm & 1.66 & 1.2 & \pm 0.3 & 15 & \pm & 5 \\
\hline 17 & $47^{\circ} 3^{\prime} 20.7^{\prime \prime} \mathrm{N}, 13^{\circ} 12^{\prime} 25.1^{\prime \prime} \mathrm{E}$ & 0.0 & 4.80 & \pm & 0.52 & 0.2 & $\pm \quad 0.2$ & 16 & \pm & 2 \\
\hline 18 & $47^{\circ} 3^{\prime} 57.7^{\prime \prime} \mathrm{N}, 13^{\circ} 9^{\prime} 55.7^{\prime \prime} \mathrm{E}$ & 0.0 & 10.25 & \pm & 1.20 & 1.6 & \pm 0.3 & 22 & \pm & 7 \\
\hline
\end{tabular}


Table 2. Structural and functional assets in glacial stream community and key invertebrate taxa.

\begin{tabular}{|c|c|c|}
\hline Asset & Evidence & References \\
\hline \multicolumn{3}{|l|}{ Structure } \\
\hline Dominance of chironomidae & Chironomidae usually represent most of the benthic invertebrate community & {$[5,6,25]$} \\
\hline Ratio Diamesinae/Orthocladiinae & $\begin{array}{l}\text { The proportion of Diamesinae in benthic habitats is high and positively related to } \\
\text { glacier cover/glacial influence }\end{array}$ & e.g., $[14,26]$ \\
\hline Distinct succession of invertebrate families & $\begin{array}{l}\text { Depending on the habitat template, invertebrate families successively colonize } \\
\text { glacier-fed streams along their longitudinal dimension }\end{array}$ & e.g., [5] \\
\hline Diversity and abundance & $\begin{array}{c}\text { Diversity rises and falls along a hump shape harsh-benign gradient, whereas } \\
\text { abundance increases with decreasing harshness. }\end{array}$ & {$[1,47]$} \\
\hline Seasonal patterns & Significant difference in community structure in winter samples & {$[48,49]$} \\
\hline Spatial and temporal heterogeneity & $\begin{array}{c}\text { Dominance of certain taxonomic groups in the invertebrate community varies } \\
\text { considerably between habitat types, along the longitudinal succession of streams, and } \\
\text { between different seasons. }\end{array}$ & {$[6,14,50-52]$} \\
\hline \multicolumn{3}{|l|}{ Function } \\
\hline Cold-hardiness & $\begin{array}{c}\text { Cold river specialists (Diamesinae) possess cold hardiness mechanisms that allows } \\
\text { winter-activity and survival at sub-zero temperatures }\end{array}$ & [32] \\
\hline Feeding plasticity & $\begin{array}{c}\text { Populations of same glacial river specialist species have variable feeding niches, } \\
\text { depending on the harshness of the habitat }\end{array}$ & {$[11,18]$} \\
\hline Food exploitation & Specificity in food items & [40] \\
\hline Body mass variability & $\begin{array}{l}\text { The body mass of same glacial river specialist species is positively related with habitat } \\
\text { harshness, whereas other species have consistent body-mass }\end{array}$ & {$[17,30]$} \\
\hline Trait variability & $\begin{array}{l}\text { Relative abundance and variability of species traits are related to degree of glacial } \\
\text { influence on particular stream habitats }\end{array}$ & {$[9,13]$} \\
\hline Life-cycle adaptation & $\begin{array}{c}\text { Alpine stream chironomid species (and especially for glacial river specialists) have } \\
\text { lower degree-day demand and faster development as larvae at colder water } \\
\text { temperatures }\end{array}$ & {$[17,19,30]$} \\
\hline
\end{tabular}


Supplementary Materials: The following are available online at http://www.mdpi.com/2073-4441/12/2/376/s1, Video S1: Most taxa colonizing streams with intermediate and no glacial influence.

Author Contributions: Both authors contributed equally to this research article, whereby the following assignments apply: conceptualization, L.F. and G.H.N.; methodology, L.F.; software, G.H.N.; validation, L.F.; formal analysis, G.H.N.; investigation, L.F. and G.H.N.; resources, L.F.; data curation, L.F.; writing-original draft preparation, L.F. and G.H.N.; writing-review and editing, L.F. and G.H.N.; visualization, G.H.N.; supervision, L.F.; project administration, L.F.; funding acquisition, L.F. and G.H.N. All authors have read and agreed to the published version of the manuscript.

Funding: This research was funded by a research fund to L.F. (project Monitoring Alpine Rivers) by the Nationalparkrat Hohe Tauern, the Federal Ministry of Agriculture, Forestry, Environment and Water (BMLFUW), the Austrian Nationalbank and the European Union, and a research grant to G.H.N. by the Tiroler Wissenschaftsfonds (project FEED-STREAM).

Acknowledgments: We are grateful to Saskia Amann, Daria Golub, Brigitte Hechenblaickner, Verena Huter, Bernhard Kofler, Simon Leinfellner, Stefan Schütz, and Bernhard Wegscheider for help in the field and to the Administration of the Hohe Tauern National Park for permission to work in these remote areas.

Conflicts of Interest: The authors declare no conflict of interest.

\section{References and Notes}

1. Brittain, J.E.; Milner, A.M. Ecology of glacier-fed rivers: Current status and concepts. Freshw. Biol. 2001, 46, 1571-1578. [CrossRef]

2. Uehlinger, U.; Malard, F.; Ward, J.V. Thermal patterns in the surface waters of a glacial river corridor (Val Roseg, Switzerland). Freshw. Biol. 2003, 48, 284-300. [CrossRef]

3. Jacobsen, D.; Dangles, O. Ecology of High Altitude Waters; Oxford University Press: Oxford, UK, 2017; ISBN 9780198736868.

4. Kneib, M.; Cauvy-Fraunié, S.; Escoffier, N.; Boix Canadell, M.; Horgby, Å.; Battin, T.J. Glacier retreat changes diurnal variation intensity and frequency of hydrologic variables in Alpine and Andean streams. J. Hydrol. 2020, 583, 124578. [CrossRef]

5. Milner, A.M.; Brittain, J.E.; Castella, E.; Petts, G.E. Trends of macroinvertebrate community structure in glacier-fed rivers in relation to environmental conditions: A synthesis. Freshw. Biol. 2001, 46, 1833-1847. [CrossRef]

6. Füreder, L.; Schütz, C.; Wallinger, M.; Burger, R. Physico-chemistry and aquatic insects of a glacier-fed and a spring-fed alpine stream. Freshw. Biol. 2001, 46, 1673-1690. [CrossRef]

7. Rott, E.; Cantonati, M.; Füreder, L.; Pfister, P. Benthic algae in high altitude streams of the Alps-A neglected component of the aquatic biota. Hydrobiologia 2006, 562, 195-216. [CrossRef]

8. Uehlinger, U.; Robinson, C.T.; Hieber, M.; Zah, R. The physico-chemical habitat template for periphyton in alpine glacial streams under a changing climate. Hydrobiologia 2010, 657, 107-121. [CrossRef]

9. Füreder, L. Life at the Edge: Habitat Condition and Bottom Fauna of Alpine Running Waters. Int. Rev. Hydrobiol. 2007, 92, 491-513. [CrossRef]

10. Zah, R.; Burgherr, P.; Bernasconi, S.M.; Uehlinger, U. Stable isotope analysis of macroinvertebrates and their food sources in a glacier stream. Freshw. Biol. 2001, 46, 871-882. [CrossRef]

11. Füreder, L.; Welter, C.; Jackson, J.K. Dietary and Stable Isotope $\left(\delta^{13} \mathrm{C}, \delta^{15} \mathrm{~N}\right)$ analyses in Alpine Stream Insects. Int. Rev. Hydrobiol. 2003, 88, 314-331. [CrossRef]

12. Füreder, L.; Welter, C.; Jackson, J.K. Dietary and stable isotope $(\delta 13 \mathrm{C}, \delta 15 \mathrm{~N})$ analyses in alpine Ephemeroptera and Plecoptera. In Proceedings of the Research Update on Ephemeroptera E Plecoptera; Gaino, E., Ed.; University of Perugia: Perugia, Italy, 2003; pp. 39-46.

13. Brown, L.E.; Khamis, K.; Wilkes, M.; Blaen, P.; Brittain, J.E.; Carrivick, J.L.; Fell, S.; Friberg, N.; Füreder, L.; Gislason, G.M.; et al. Functional diversity and community assembly of river invertebrates show globally consistent responses to decreasing glacier cover. Nat. Ecol. Evol. 2018, 2, 325-333. [CrossRef] [PubMed]

14. Niedrist, G.H.; Füreder, L. Towards a definition of environmental niches in alpine streams by employing chironomid species preferences. Hydrobiologia 2016, 781, 143-160. [CrossRef]

15. Niedrist, G.H.; Füreder, L. Real-time warming of high-altitude streams: (Re)defining invertebrates' temperature preferences. River Res. Appl. 
16. Cauvy-Fraunié, S.; Dangles, O. A global synthesis of biodiversity responses to glacier retreat. Nat. Ecol. Evol. 2019, 3, 1675-1685. [CrossRef] [PubMed]

17. Niedrist, G.H.; Cantonati, M.; Füreder, L. Environmental harshness mediates the quality of periphyton and chironomid body mass in alpine streams. Freshw. Sci. 2018, 37, 519-533. [CrossRef]

18. Niedrist, G.H.; Füreder, L. When the going gets tough, the tough get going: The enigma of survival strategies in harsh glacial stream environments. Freshw. Biol. 2018, 63, 1260-1272. [CrossRef]

19. Schütz, S.A.; Füreder, L. Egg development and hatching success in alpine chironomids. Freshw. Biol. 2019, 64, 685-696. [CrossRef]

20. QGIS Development Team QGIS Geographic Information System. Open Source Geospatial Foundation Project. 2009.

21. Jackson, A.L.; Inger, R.; Parnell, A.C.; Bearhop, S. Comparing isotopic niche widths among and within communities: SIBER-Stable Isotope Bayesian Ellipses in R. J. Anim. Ecol. 2011, 80, 595-602. [CrossRef]

22. Nolte, U. Chironomid biomass determination from larval shape. Freshw. Biol. 1990, 24, 443-451. [CrossRef]

23. Tod, S.P.; Schmid-Araya, J.M. Meiofauna versus macrofauna: Secondary production of invertebrates in a lowland chalk stream. Limnol. Oceanogr. 2009, 54, 450-456. [CrossRef]

24. Lods-Crozet, B.; Lencioni, V.; Olafsson, J.S.; Snook, D.L.; Velle, G.; Brittain, J.E.; Castella, E.; Rossaro, B. Chironomid (Diptera: Chironomidae) communities in six European glacier-fed streams. Freshw. Biol. 2001, 46, 1791-1809. [CrossRef]

25. Castella, E.; Adalsteinsson, H.; Brittain, J.E.; Gislason, G.M.; Lehmann, A.; Lencioni, V.; Lods-Crozet, B.; Maiolini, B.; Milner, A.M.; Olafsson, J.S.; et al. Macrobenthic invertebrate richness and composition along a latitudinal gradient of European glacier-fed streams. Freshw. Biol. 2001, 46, 1811-1831. [CrossRef]

26. Maiolini, B.; Lencioni, V. Longitudinal distribution of macroinvertebrate assemblages in a glacially influenced stream system in the Italian Alps. Freshw. Biol. 2001, 46, 1625-1639. [CrossRef]

27. Jacobsen, D.; Dangles, O. Environmental harshness and global richness patterns in glacier-fed streams. Glob. Ecol. Biogeogr. 2012, 21, 647-656. [CrossRef]

28. Füreder, L. High alpine streams: Cold habitats for insect larvae. In Cold-Adapted Organisms; Margesin, R., Schinner, F., Eds.; Springer: Berlin/Heidelberg, Germany, 1999; pp. 181-196. ISBN 978-3-662-06285-2.

29. Lods-Crozet, B.; Lencioni, V.; Brittain, J.E.; Marziali, L.; Rossaro, B. Contrasting chironomid assemblages in two high Arctic streams on Svalbard. Fundam. Appl. Limnol. 2007, 170, 211-222. [CrossRef]

30. Schütz, S.; Füreder, L. Unexpected patterns of chironomid larval size in an extreme environment: A highly glaciated, alpine stream. Hydrobiologia 2018, 820, 49-63. [CrossRef]

31. Pritchard, G.; Harder, L.D.; Mutch, R.A. Development of aquatic insect eggs in relation to temperature and strategies for dealing with different thermal environments. Biol. J. Linn. Soc. 1996, 58, 221-244. [CrossRef]

32. Lencioni, V.; Jousson, O.; Guella, G.; Bernabò, P. Cold adaptive potential of chironomids overwintering in a glacial stream. Physiol. Entomol. 2015, 40, 43-53. [CrossRef]

33. Pankhurst, N.W.; Munday, P.L. Effects of climate change on fish reproduction and early life history stages. Mar. Freshw. Res. 2011, 62, 1015-1026. [CrossRef]

34. Humpesch, U.H.; Elliott, J.M. Effect of Temperature on the Hatching Time of Eggs of Three Rhithrogena Spp. (Ephemeroptera) from Austrian Streams and an English Stream and River. J. Anim. Ecol. 1980, 49, 643. [CrossRef]

35. Knispel, S.; Sartori, M.; Brittain, J.E. Egg development in the mayflies of a Swiss glacial floodplain. J. N. Am. Benthol. Soc. 2006, 25, 430-443. [CrossRef]

36. Lillehamnur, A.; Brittain, J.E.; Saltveit, S.J.; Nielsen, P.S. Egg development, nymphal growth and life cycle strategies in Plecoptera. Ecography 1989, 12, 173-186. [CrossRef]

37. Clitherow, L.R.; Carrivick, J.L.; Brown, L.E. Food Web Structure in a Harsh Glacier-Fed River. PLoS ONE 2013, 8, e60899. [CrossRef] [PubMed]

38. Knight, J.; Harrison, S. Sediments and future climate. Nat. Geosci. 2009, 2, 230. [CrossRef]

39. Niedrist, G.H.; Füreder, L. Real-time warming of high-altitude streams and potential consequences within invertebrate communities. Clim. Chang. Biol.

40. Niedrist, G.H.; Füreder, L. Trophic ecology of alpine stream invertebrates: Current status and future research needs. Freshw. Sci. 2017, 36, 466-478. [CrossRef]

41. Hieber, M.M.; Robinson, C.T.; Rushforth, S.R.; Uehlinger, U. Algal communities associated with different alpine stream types. Arctic Antarct. Alp. Res. 2001, 33, 447-456. [CrossRef] 
42. Klaveness, D. Hydrurus foetidus (Chrysophyceae): An update and request for observations. Algae 2019, 34, 1-5. [CrossRef]

43. Galloway, A.W.E.; Winder, M. Partitioning the Relative Importance of Phylogeny and Environmental Conditions on Phytoplankton Fatty Acids. PLoS ONE 2015, 10, e0130053. [CrossRef]

44. Twining, C.W.; Brenna, J.T.; Hairston, N.G.; Flecker, A.S. Highly unsaturated fatty acids in nature: What we know and what we need to learn. Oikos 2016, 125, 749-760. [CrossRef]

45. Zemp, M.; Frey, H.; Gärtner-Roer, I.; Nussbaumer, S.U.; Hoelzle, M.; Paul, F.; Haeberli, W.; Denzinger, F.; Ahlstrøm, A.P.; Anderson, B.; et al. Historically unprecedented global glacier decline in the early 21st century. J. Glaciol. 2015, 61, 745-762. [CrossRef]

46. Hock, R.; Rasul, G.; Adler, C.; Cáceres, B.; Gruber, S.; Hirabayashi, Y.; Jackson, M.; Kääb, A.; Kang, S.; Kutuzov, S.; et al. High Mountain Areas. In IPCC Special Report on the Ocean and Cryosphere in a Changing Climate; Pörtner, H.-O., Roberts, D.C., Masson-Delmotte, V., Zhai, P., Tignor, M., Poloczanska, E., Mintenbeck, K., Alegría, A., Nicolai, M., Okem, A., et al., Eds.; IPCC: Genf, Switzerland, 2019; p. 72.

47. Ward, J.V.; Uehlinger, U. Ecology of a Glacial Flood Plain; Springer: Dordrecht, The Netherlands, 2003; ISBN 978-1-4020-1792-6.

48. Füreder, L.; Schütz, C.; Burger, R.; Wallinger, M. Seasonal abundance and community structure of Chironomidae in two contrasting high alpine streams. SIL Proc. 2000, 27, 1596-1601. [CrossRef]

49. Schütz, C.; Wallinger, M.; Burger, R.; Füreder, L. Effects of snow cover on the benthic fauna in a glacier-fed stream. Freshw. Biol. 2001, 46, 1691-1704. [CrossRef]

50. Martyniuk, N.; Modenutti, B.; Balseiro, E.G. Seasonal variability in glacial influence affects macroinvertebrate assemblages in North-Andean Patagonian glacier-fed streams. Inl. Waters 2019, 9, 522-533. [CrossRef]

51. Tockner, W. Tockner Biodiversity: Towards a unifying theme for river ecology. Freshw. Biol. 2001, 46, 807-819.

52. Scotti, A.; Jacobsen, D.; Tappeiner, U.; Bottarin, R. Spatial and temporal variation of benthic macroinvertebrate assemblages during the glacial melt season in an Italian glacier-fed stream. Hydrobiologia 2019, 827, 123-139. [CrossRef]

(C) 2020 by the authors. Licensee MDPI, Basel, Switzerland. This article is an open access article distributed under the terms and conditions of the Creative Commons Attribution (CC BY) license (http://creativecommons.org/licenses/by/4.0/). 